\section{Gunnar Sigurðsson}

sérfræðingur í innkirtlasjúkdómum Stjórnarformaður Hjartaverndar 1998-2016

gunnars@hjarta.is

\title{
Reykjavíkurrannsókn Hjartaverndar 50 ára
}

Reykjavíkurrannsókn Hjartaverndar hófst um leið og Rannsóknarstöð Hjartaverndar opnaði að Lágmúla 9, í október 1967. Pví er liðin hálf öld síðan rannsóknin hófst að frumkvæði Sigurðar Samúelssonar prófessors og samstarfsfólks, nánar lýst áđur í Læknablaðinu. ${ }^{1}$

Megintilgangur hennar var að gera umfangsmikla hóprannsókn til að kanna meðal annars útbreiðslu hjarta- og æðasjúkdóma hér á landi og finna helstu áhættupættina svo unnt yrði að beita árangursríkum forvörnum gegn pessum faraldri.

Reykjavíkurrannsóknin var sérstök í alpjóðlegu samhengi par sem hún náði til stórs hóps beggja kynja, um 19.000 manns sem fylgt var eftir um langt árabil. Pátttakendahópurinn var um priðjungur íslensku pjóðarinnar, fæddir 1907-1934, á aldrinum 34-69 ára við val hópsins 1967. Upplýsingasöfnunin var um 800 atriði varðandi hvern einstakling, fyrstu tölvuskráðu sjúkraskrárnar á Íslandi. Hver pátttakandi kom allt að fimm sinnum í hóprannsóknina á árabilinu 1967-1997. Á árinu 1981 hóf Rannsóknarstöð Hjartaverndar fyrir Íslands hönd pátttöku í fjölpjóðlegri rannsókn Alpjóðaheilbrigðismálastofnunarinnar á hjarta- og æðasjúkdómum sem fékk nafnið MONICA. Nikulás Sigfússon yfirlæknir stjórnaði rannsókninni hér á landi. Skráð voru öll kransæðatilfelli á landinu, 25-74 ára, sem gaf viðbótarmöguleika á tengingu áhættupátta við algengi kransæðasjúkdóma, ekki eingöngu við dánarorsakir eins og áður. Hjartavernd hefur haldið áfram pessari skráningu síðan. Samtvinnun pessara gagnasafna, svo og gagna síðari hóprannsókna Hjartaverndar, hefur verið nýtt til að fylgjast með próun kransæðasjúkdóma á Íslandi og helstu áhættupáttanna í nær hálfa öld eins og lýst er í ítarlegri yfirlitsgrein pessa tölublaðs Læknablaðsins. ${ }^{2}$ Greinin lýsir vel breytingum sem orðið hafa hér á landi síðustu áratugina. Tengsl lækkunar á tíðni kransæðasjúkdóma á Íslandi við breytingar á áhættupáttum voru fyrst könnuð fyrir tímabilið 1968-1988 og sýndu niðurstöðurnar að skýra mætti fækkun kransæðatilfella sem pá var orðin að stórum hluta (75\%) út frá æskilegum breytingum á helstu áhættupáttunum. Hjartavernd var með peim fyrstu til að sýna fram á petta í vísindagrein í British Medical Journal árið 1991 sem hlaut verðskuldaða athygli. ${ }^{3}$

Upplýsingarnar hafa verið nýttar á undaförnum áratugum í árangursríkri baráttu við hjarta- og æðasjúkdóma og áhættupættina á Íslandi, sem var aðaltilgangur með stofnun Hjartaverndar á sínum tíma. ${ }^{1}$ Niðurstöðurnar sýndu til dæmis að á 10. áratug síðustu aldar mátti rekja priðja hvert dauðsfall í aldurshópi 35-69 ára til reykinga og á pessum tíma dó að meðaltali einn Íslendingur á dag úr reykingatengdum sjúkdómum (hjarta- og æðasjúkdómar, lungnasjúkdómar og krabbamein). Á árinu 2006 voru dauðsföllin vegna pessa um 100 færri á ári samfara minni reykingum. ${ }^{2}$

Hluti eftirlifandi pátttakendahóps Reykjavíkurrannsóknarinnar (5764 manns) varð síðan að undirstöðu Öldrunarrannsóknar Hjartaverndar sem hófst árið 2002.

Reykjarvíkurrannsóknin hefur einnig gefið möguleika á athugun á öðrum hugsanlegum áhættupáttum og mismunandi myndum kransæðasjúkdóms meðal karla og kvenna. ${ }^{1}$ Petta leiddi í ljós áður lítt pekktar upplýsingar svo sem að karlar sem fengið höfðu pögla kransæðastíflu (án einkenna) höfðu svipaðar horfur og aðrir með sögu um pekkta kransæðastíflu. ${ }^{4}$ Petta hefur svo verið athugað nánar í Öldrunarrannsókninni.

Gagnasafn Reykjavíkurrannsóknarinnar hefur einnig verið nýtt til rannsókna á öðrum langvinnum sjúkdómum á Íslandi. Í pessu tölublaði Læknablaðsins birtist yfirlit um beinbrot í öllum pátttakendahópnum, sem gefur innsýn í faraldsfræði helstu beinpynningarbrota á Íslandi síðustu áratugi. ${ }^{5}$ Niðurstöðurnar benda til lægri tíðni mjaðmarbrota frá aldamótum, sem gæti átt sér margar skýringar. Par sem rannsóknarhópur Reykjavíkurrannsóknarinnar nýtist ekki til frekari athugunar á pessu pyrfti önnur rannsókn að taka við. Eðlilegast væri að komið yrði á árlegri skráningu mjaðmarbrota og helstu beinpynningarbrota fyrir allt landið.

Rannsóknarstöð Hjartaverndar hefur unnið mikið og merkt starf síðastliðna hálfa öld undir farsælli forystu læknanna Ólafs Ólafssonar, Nikulásar Sigfússonar og Vilmundar Guðnasonar.

\section{Heimildir}

1. Gudnason V, Sigfusson N, Sigurdsson G. Rannsóknarstöð Hjartaverndar í fortíð og nútíð. Laeknabladid, 2014; 100:456-464.

2. Andersen K, Aspelund T, Gudmundsson E, Siggeirsdottir K, Thorolfsdottir RB, Sigurdsson G, et al. Úr gögnum Hjartaverndar: Faraldsfræði kransæðasjúkdoma á Íslandi í hálfa öld. Laeknabladid, 2017; 103:411-420.

3. Sigfusson N, Sigvaldason H, Steingrimsdottir L, Gudmundsdottir II, Stefansdottir I, Thorsteinsson T, Sigurdsson G. Decline in ischaemic heart disease in Iceland and change in risk factor levels. BMJ 1991; 302: 1371-5.

4. Sigurdsson E, Thorgeirsson G, Sigvaldason H, Sigfusson N. Unrecognized myocardial infarction: epidemiology, clinical characteristics, and the prognostic role of angina pectoris. The Reykjavik Study. Ann Int Med 1995; 122: 96-102.

5. Sigurðsson G, Siggeirsdóttir K, Jónsson BY, Mogensen B, Guðmundsson EF, Aspelund T, et al. Úr gögnum Hjartaverndar: Nokkur atriði um faraldsfræði og áhættumat beinbrota á Íslandi. Laeknabladid, 2017; 103:423-428. 